\title{
The Rhone river dilution zone present in the northeastern shelf of the Gulf of Lion in December 2003
}

\author{
Julie Gatti $^{\mathrm{a}, *}$, Anne Petrenko ${ }^{\mathrm{a}}$, Jean-Luc Devenon ${ }^{\mathrm{a}}$, Yann Leredde ${ }^{\mathrm{b}}$, Caroline Ulses ${ }^{\mathrm{c}}$ \\ ${ }^{a}$ Laboratoire d'Océanographie et de Biogéochimie, UMR 6535 CNRS/Université de la Méditerranée, OSU/Centre d'Océanologie de \\ Marseille, Campus de Luminy case 901, 13288 Marseille Cedex 9, France \\ ${ }^{\mathrm{b}}$ Laboratoire de Dynamique de la Lithosphère, UMR 5573 CNRS/Université Montpellier 2. 60, place E. Bataillon. \\ 34095 Montpellier Cedex 5, France \\ ${ }^{\mathrm{c}}$ Laboratoire d'Aérologie, UMR 5560 CNRS/Université Paul Sabatier, 14 avenue E. Belin, 31400 Toulouse, France
}

\begin{abstract}
Acoustic doppler current profiler (ADCP), CTD and thermosalinograph data from the Gulf Of Lion Time Series (GOLTS) cruise of December 2003, and corresponding AVHRR images, show the unusual presence of the Rhone river dilution zone far east from the Rhone river mouth. It is the first time this event is studied with simultaneous hydrological and current data. This dilution zone extends as far as $5.27^{\circ} \mathrm{E}$ in longitude $\left(45 \mathrm{~km}\right.$ from the Rhone river mouth). At longitude $5.13^{\circ} \mathrm{E}(37$ $\mathrm{km}$ from the Rhone river mouth), the dilution zone is $40 \mathrm{~m}$ deep and spreads over $0.075^{\circ}$ latitude $(8 \mathrm{~km})$. It is due to an eastward current present there throughout the ADCP-detected range $(12-120 \mathrm{~m})$. The analysis of moored ADCP time series reveals that such eastward currents occur there about $18 \%$ of the time and that diluted waters from the Rhone reach the Station d'Observation Fixe (SOFI) site between 3.9\% and 8.4\% of the time. This December 2003 event is the consequence of the combined effects of a storm with east winds and the presence of freshwater along the coast.
\end{abstract}

Keywords: River plumes; Shelf dynamics; Current data (ADCP); Cruise stations; AVHRR images; Gulf of Lion

\section{Introduction}

Since the construction of the Aswan dam and the consecutive reduction of the Nile river inflows, the Rhone River has become the most significant source of freshwater in the microtidal Mediterranean Sea (Fig. 1). Its mean freshwater discharge is around $1700 \mathrm{~m}^{3} \mathrm{~s}^{-1}$, and it represents $90 \%$ of the total

\footnotetext{
*Corresponding author. Tel.: + 33491829061 ; fax: +33491821991 .

E-mail address: gatti@com.univ-mrs.fr (J. Gatti).
}

freshwater input in the Gulf of Lion's (GoL) continental shelf (Fieux, 1974; Durrieu de Madron et al., 2003). It is also a major nutrient source for the GoL, and influences its productivity (Coste, 1974; Morel et al., 1990) and fishery activities. The Rhone River produces a surface plume, which bends to its right (facing seaward) due to the Coriolis acceleration (in the northern hemisphere), and flows westward. Indeed, the Rhone river plume presents a Kelvin number greater than one and is thus submitted to strong Coriolis effects. The particularity of the Rhone plume is that both its Kelvin 


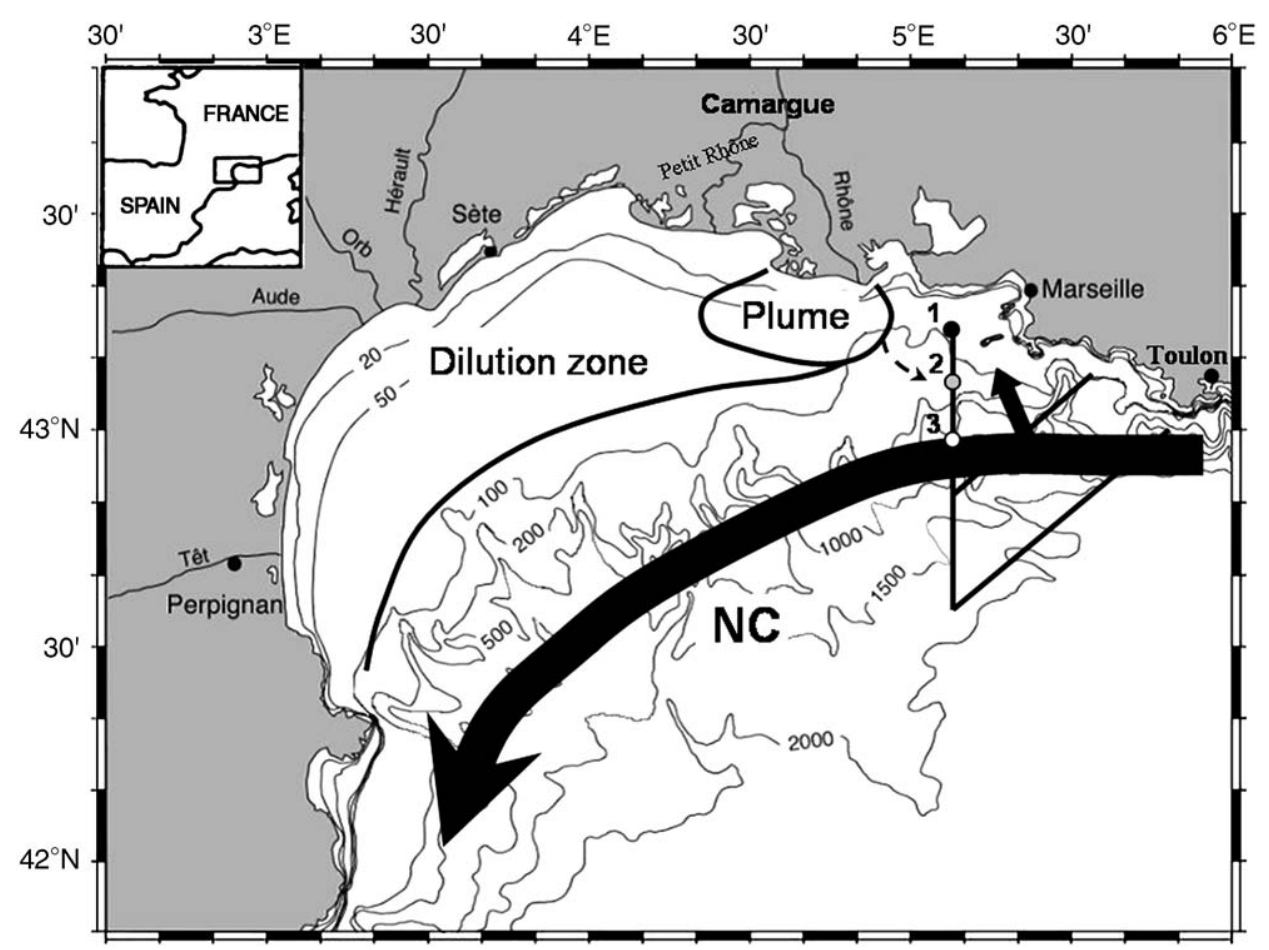

Fig. 1. Map of the Gulf of Lion (kindly provided by Xavier Durrieu De Madron, and adapted from the Ifremer bathymetric map of the Gulf of Lion); the Rhone plume with its dilution zone and its potential eastern extension (dotted arrow), the NC and one of its intrusion (arrows), the GOLTS cruise transects with the CTD stations (dots). The SOFI site corresponds to CTD Station 2 (grey dot). Isobaths at $20,50,100,200,500,1000,1500,2000 \mathrm{~m}$ are drawn.

number and its Froude number $(\mathrm{Fr})$ are greater than one (calculated from observations in ArnouxChiavassa (1998); from modelling results in Marsaleix et al. (1998)). Whereas, according to the Garvine's classification system (Garvine, 1995), low Kelvin numbers are normally associated to supercritical plumes (Fr $>1$; Chao, 1988) and, inversely, high Kelvin numbers to low Fr.

The Rhone plume dynamics have been studied with both remote sensing observations (Demarcq, 1985; Forget et al., 1990; Devenon et al., 1992; Broche et al., 1998) and modelling studies (Estournel et al., 1997; Marsaleix et al., 1998; Estournel et al., 2001; Arnoux-Chiavassa et al., 2003; Reffray et al., 2004). All these studies show that the extent and thickness of the Rhone river plume depend on the Rhone discharge, the meteorological conditions and the surrounding circulations (except the tidal currents which are practically nonexistent in this region).

Two wind regimes are predominant in the GoL and induce two types of plume. Under northnorthwest winds (upwelling favourable winds), the plume extends offshore towards the southwest.
Whereas southeast winds (downwelling favourable winds) push and constrain the plume to the coast, west of the Rhone river outlet (Estournel et al., 1997). A third type of plume is encountered after the less frequent west winds. They deviate the plume toward the southeast (Demarcq, 1985), at $22 \mathrm{~km}$ (limit of detection of the VHF radar) from the river mouth in the work of Broche et al. (1998).

In the Rhone river dilution area (corresponding to salinities lower than 37.8), the wind intensity influences the plume by increasing its mixing with the surrounding waters (Estournel et al., 1997). At the Rhone river mouth, the plume is a few meters deep. The thickness of this freshwater surface layer increases along its trajectory under strong winds (Broche et al., 1998; Xing and Davies, 1999). The layer influenced by the dilution of the Rhone river plume was $60 \mathrm{~m}$ deep at $60 \mathrm{~km}$ southwest of the river mouth during the FETCH experiment in 1998 (Estournel et al., 2003). While Conan (1996) observed it down to $30 \mathrm{~m}$ at about $40 \mathrm{~km}$ east of the river mouth.

The main general circulation feature influencing the GoL is the Northern Current (NC; Fig. 1). The 
$\mathrm{NC}$, flowing along the continental slope from east to west (Millot, 1990), can occasionally intrude on the shelf (Millot and Wald, 1980; Petrenko, 2003). The main objective of the Gulf Of Lion Time Series (GOLTS) project is to study the NC's intrusions on the continental shelf of the GoL.

During the GOLTS cruises of December 2002 and 2003, an extension of the Rhone dilution zone was unusually observed in the northeastern shelf of the GoL, whereas it is generally considered to spread over only a few $\mathrm{km}$ towards the east of the river mouth (Minas and Minas, 1989). Hence its potential inputs of nutrients (Coste and Raimbault, 1993) and pollutants (UNEP report, 1984) can influence an area larger than expected, and moreover, reach densely-habited coasts (population of more than one million of inhabitants). Diluted Coastal Waters (CW) from the Rhone River $(S<37.8$, Conan, 1996) have already been detected at the Station d'Observation Fixe (SOFI) site $\left(5.13^{\circ} \mathrm{E}\right.$ and $43.07^{\circ} \mathrm{N}$; Fig. 1) with CTD data. Diaz (2000) mentioned the presence of CW at the SOFI site four times during 1998, and Leblanc et al. (2003) observed them once in July 2000. Otherwise, as mentioned earlier, Conan (1996) showed that, in October 1992, CW were present at more than $40 \mathrm{~km}$ from the Rhone river mouth $\left(5.21^{\circ} \mathrm{E}\right.$ and $\left.43.03^{\circ} \mathrm{N}\right)$. But no current data were available in these previous studies.

This paper aims at completely describing this singular eastern extent of the Rhone river dilution zone in the Results section (Section 3). The results of December 2003, but not those of December 2002, will be presented since only the former highlight a complete spatial and temporal evolution of the eastern extent of the Rhone dilution zone. Then, the Discussion section (Section 4) offers possible explanations for its generating process.

\section{Material and methods}

Data were collected during the GOLTS cruise, which took place on board of the RV Tethys II from December 8 to 12,2003 . This cruise is a component of the GOLTS project (2002-2004), which is designed to observe and quantify the NC's intrusions on the eastern part of the GoL's continental shelf. The in situ experiments of the GOLTS project include two main components: time series collected at a moored acoustic doppler current profiler (ADCP) and cruises.

The ADCP (RDI Ocean Sentinel $300 \mathrm{kHz}$ ) is moored on the bottom depth at the SOFI site ( $\sim 165 \mathrm{~m}$ depth), on the edge of the continental shelf. Since November 2001, it provides current time series, every $1 / 2 \mathrm{~h}$ and every $4 \mathrm{~m}$ depth.

Five-day surveys have then been planned, every 6 months since June 2002, to collect the moored ADCP's data at the SOFI site and acquire continuous measurements along specific transects. The RV Tethys II follows pre-defined transects, starting from Marseille and covering the key zone of the potential entrance of the NC on the GoL (Fig. 1). Continuously measured data are: sea surface temperature, sea surface salinity and currents' profiles. They are collected, respectively, with a Seabird thermosalinograph connected to an underway pump and with a hull-mounted ADCP (RDI BroadBand $150 \mathrm{kHz}$ ). For each cruise, the same ADCP configuration is used: 60 cells of $4 \mathrm{~m}$ depth, an ensemble average of $1 \mathrm{~min}$ and bottom tracking when possible. ADCP data analysis is done by the French INSU (Institut National des Sciences de l'Univers). Moreover, hydrological profiles are regularly made with a CTD at pre-chosen stations (Fig. 1).

NOAA/AVHRR satellite images are provided in quasi-real time by Météo-France. These fourth

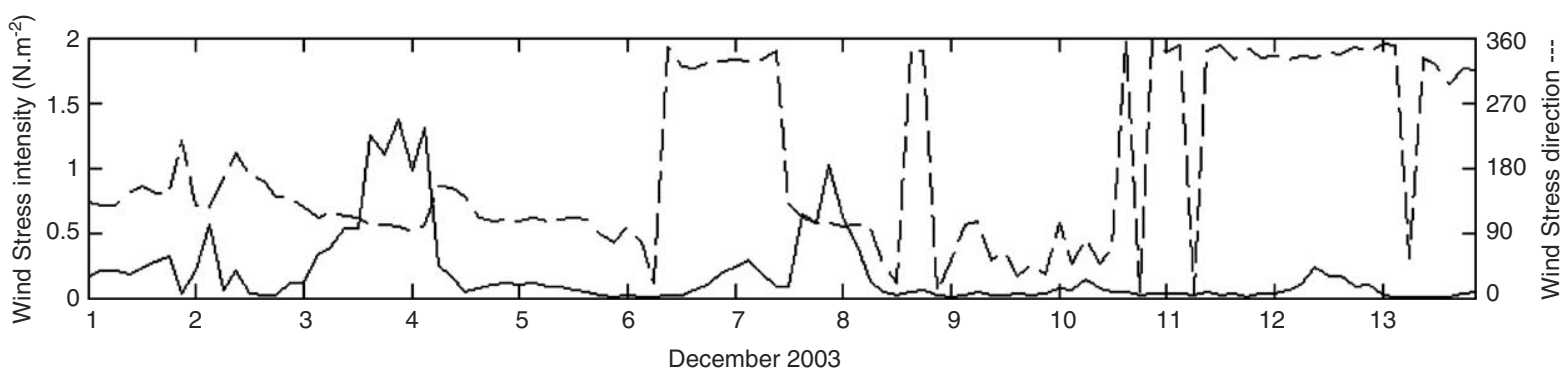

Fig. 2. Wind stress intensity (solid line) and direction (dashed line) at SOFI in December 2003. Results from the ALADIN model. A wind stress intensity of $1 \mathrm{~N} \mathrm{~m}^{-2}$ corresponds to a wind intensity of $20 \mathrm{~m} \mathrm{~s}^{-1}$. 
infrared band data are the so-called "brilliance temperature" (range: $5-30.5{ }^{\circ} \mathrm{C}$ with a $0.1{ }^{\circ} \mathrm{C}$ resolution). During the cruise, the AVHRR temperature has a negative anomaly of $2{ }^{\circ} \mathrm{C}$ compared to in situ data (not show).

Wind data throughout the GoL $\left(0.1-0.1^{\circ}\right.$ grid and a $3 \mathrm{~h}$ averaged period) are modelled with ALADIN by Météo-France (Fig. 2). The daily inputs of the Grand Rhone, measured at the Beaucaire station, are provided by the "Compagnie Nationale du Rhone".

\section{Results}

\subsection{Environmental conditions}

The GOLTS cruise occurred after quite outstanding events of river discharge and precipitation. Indeed, the Rhone exceeded the flow limit corresponding to a 50 -year flood $\left(>10,000 \mathrm{~m}^{3} \mathrm{~s}^{-1}\right)$ on December 3-4, 2003. The consequence was catastrophic floodings in the Camargue region. From December 5 to the cruise period, the Rhone river flow decreased and remained around its usual seasonal value $\left(1700 \mathrm{~m}^{3} \mathrm{~s}^{-1}\right)$.

Simultaneously to this exceptional flood, there was a storm with strong east winds (up to $22 \mathrm{~m} \mathrm{~s}^{-1}$ ) during December 3-4, which constrained the Rhone river waters to the coast (Fig. 2). Then the wind weakened and changed to northwest (Mistral). Just before the cruise, on December 7, a strong east wind (up to $20 \mathrm{~m} \mathrm{~s}^{-1}$ ) blew. It lasted around $24 \mathrm{~h}$ and stopped on December 8. At Sète, on the northwestern side of the GoL (Fig. 1), coastal tide gauge data showed a high surface elevation anomaly of around $10 \mathrm{~cm}$ (data not shown) on December 7 .

\subsection{Satellite images}

Durand et al. (2002) consider that, in microtidal sea, the frontal structure of supercritical plumes is clearly visible on satellite images. On the AVHRR images available during this cruise, the $13.5^{\circ} \mathrm{C}$ isotherm constitutes the border between the Rhone plume dilution zone that spreads to the east, and the NC's waters (Fig. 3). The $13.5^{\circ} \mathrm{C}$ isotherm on the AVHRR images corresponds to a $15.5^{\circ} \mathrm{C}$ isotherm on the in situ data. The salinity corresponding to an in situ temperature of $15.5^{\circ} \mathrm{C}$ is 37.8 , our limit to define the Rhone river dilution zone. The Rhone river plume is directed southwestward while a tongue-shaped extent goes southeastward, contrary

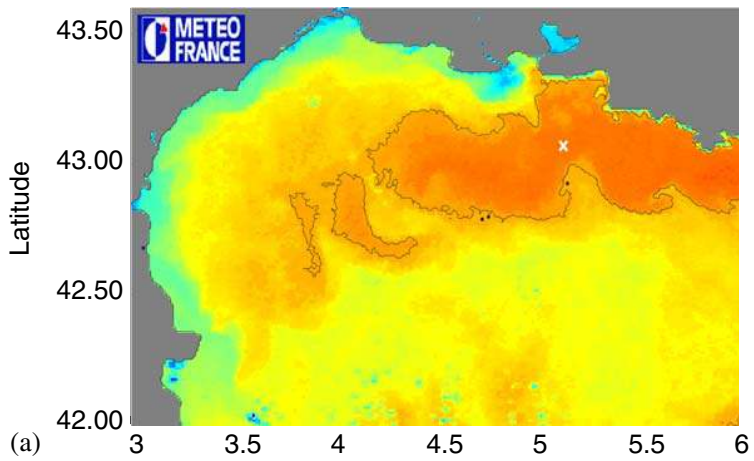

(b)
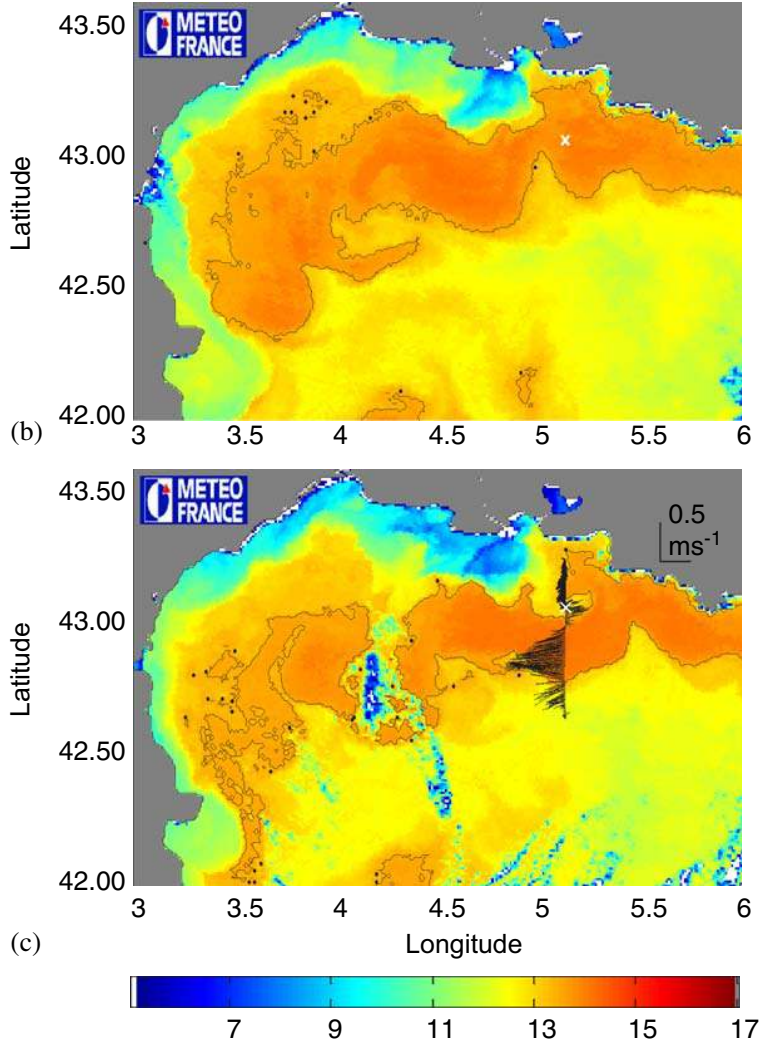

Fig. 3. AVHRR images of relative sea surface temperature $\left({ }^{\circ} \mathrm{C}\right)$ : (a) on December 8 at $12 \mathrm{~h} 45 \mathrm{~min}$, (b) on December 9 at $02 \mathrm{~h}$ $43 \mathrm{~min}$ and (c) on December 11 at $02 \mathrm{~h} 20 \mathrm{~min}$. Colour scale goes from 5 to $17^{\circ} \mathrm{C}$ and the $13.5^{\circ} \mathrm{C}$ isotherm is drawn in black. ADCP currents measured at $24 \mathrm{~m}$ depth are shown in black for (c). The SOFI site is marked with a white cross.

to the Coriolis direction. The AVHRR $13.5^{\circ} \mathrm{C}$ isotherm also clearly shows the $\mathrm{NC}$ and its meander.

On December 8 and 9, the Rhone river dilution zone extends towards the east until $5.07^{\circ} \mathrm{E}$ (Fig. 3(a) and (b)). On December 11, it reaches the SOFI mooring (Fig. 3(c)) and goes even further to the east $\left(5.27^{\circ} \mathrm{E}\right)$, at approximately $45 \mathrm{~km}$ from the Rhone river mouth. 
The superposition of the December 11 AVHRR image with the currents measured at $24 \mathrm{~m}$ depth along the $5.13^{\circ} \mathrm{E}$ transect exhibits the excellent agreement between the eastern extent of the dilution zone and an eastward current (Fig. 3(c)).

\subsection{The dilution zone and the eastward current}

The surface temperature and surface salinity data, measured along the $5.13^{\circ} \mathrm{E}$ transect, exhibit lower values in the eastern extent of the dilution zone than in surrounding waters (Fig. 4(a) and (b)). This dilution zone, located between $43.025^{\circ} \mathrm{N}$ and $43.2^{\circ} \mathrm{N}$, can be divided in two. In the southern part (south of $43.1^{\circ} \mathrm{N}$ ), temperature and salinity are reaching their minima (respectively, $14.7^{\circ} \mathrm{C}$ and 36.9). In the northern part, temperature and salinity have values between those of the ambient waters and the minima previously described. It is interesting to notice that the southern part corresponds to the position of the transect where the eastward current has been measured (Fig. 4(c)). South of this eastward current, between $43.025^{\circ} \mathrm{N}$ and $42.65^{\circ} \mathrm{N}$, the strong westward current is the NC.
The vertical section of the currents along this transect shows that the eastward current is present from the surface to the deepest cell $(\sim 120 \mathrm{~m})$ detected by the ADCP (Fig. 5). The flux of this barotropic eastward current is about $0.16 \mathrm{~Sv}$ $\left(1 \mathrm{~Sv}=10^{6} \mathrm{~m}^{3} \mathrm{~s}^{-1}\right)$, which represents about $14 \%$ of the NC flux, on December 10. On December 8, the eastward current was not present on the $5.13^{\circ} \mathrm{E}$ transect. It appeared on December 9 but was slightly further north than on December 10 (data not shown).

\subsection{Vertical profiles of temperature and salinity}

CTD profiles measured during the cruise provide the vertical range of the eastern extent of the dilution zone (Fig. 6). On the $5.13^{\circ} \mathrm{E}$ transect, three typical stations are purposefully described from south to north: Station 3 located in the NC $(U<0$ on Fig. 6(c), the NC goes westward); Station 2, at the SOFI mooring, in the eastward current $(U>0$ on Fig. 6(c)); and Station 1 in the coastal region with nearly no currents (Fig. 6(c)).

At Station $3\left(42.93^{\circ} \mathrm{N}\right)$, the $\mathrm{NC}$ carries warm $\left(16^{\circ} \mathrm{C}\right)$ and relatively salty (38) waters. The

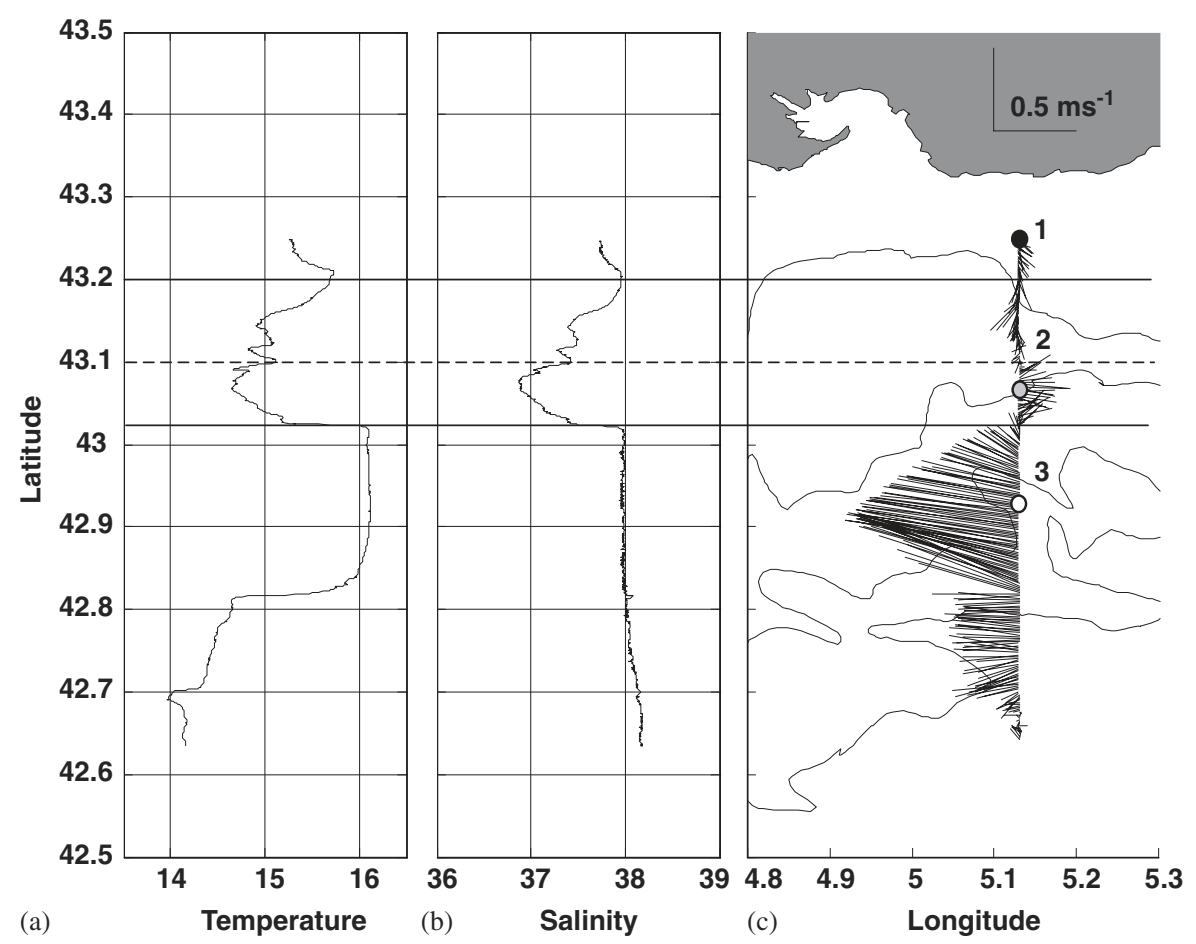

Fig. 4. (a) Surface temperature $\left({ }^{\circ} \mathrm{C}\right)$, (b) surface salinity, and (c) currents $\left(\mathrm{m} \mathrm{s}^{-1}\right)$ at $24 \mathrm{~m}$ on December 10 along the $5.13^{\circ} \mathrm{E}$ transect. Three CTD stations are marked with dots: Station 1 in black, Station 2 in grey and Station 3 in white. Isobaths at 100, 200, 1000 and 1500 m are drawn. The horizontal lines delimit the dilution zone. 


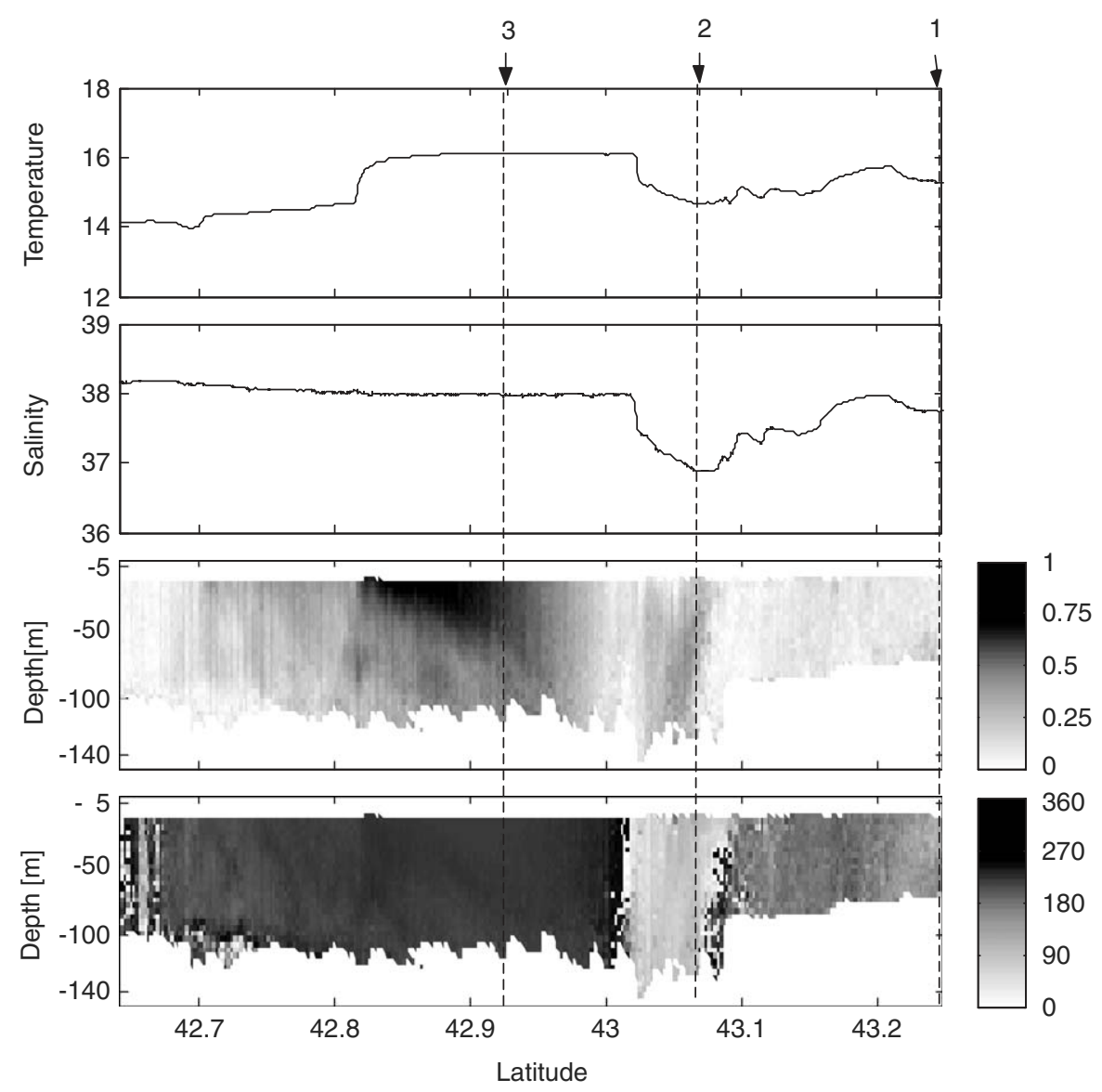

Fig. 5. Surface temperature $\left({ }^{\circ} \mathrm{C}\right)$, surface salinity, and vertical section of the current intensity $\left(\mathrm{m} \mathrm{s}^{-1}\right)$ and the current direction $\left({ }^{\circ}\right)$ along the $5.13^{\circ} \mathrm{E}$ transect on December 10 (top to bottom). The location of the three CTD stations shown on Fig. 4 are indicated with dashed lines.

temperature decreases progressively with depth to reach, at about $170 \mathrm{~m}$ depth, the value of $13.5^{\circ} \mathrm{C}$, typical temperature of the Modified Atlantic Water (MAW) (Albérola and Millot, 2003).

At Station $2\left(43.07^{\circ} \mathrm{N}\right)$, both temperature and salinity are smaller (respectively, by $1{ }^{\circ} \mathrm{C}$ and 0.9 units) than the ones measured at Station 3. These low values, characteristic of the eastern extent of the dilution zone, are clearly detectable on the first $40 \mathrm{~m}$.

At Station $1\left(43.25^{\circ} \mathrm{N}\right)$, the temperature profile is rather similar to the one of Station 2 and the upper layer salinity is between the ones of Stations 2 and 3 . These characteristics correspond to waters mixed between the Rhone river dilution zone and the surrounding waters, as explained previously for surface data.

Focusing on the temporal evolution of the CTD profiles made at Station 2 (Fig. 7), it appears that the eastern extent of the dilution zone is present there from December 10 (4 p.m.) to December 12 (3 a.m.). On December 12, the salinity is still lower in the first $20 \mathrm{~m}$ than in the deeper layers. Hence the Rhone river dilution zone is present at the site for at least $35 \mathrm{~h}$.

\subsection{Moored ADCP time series}

Horizontal currents measured with the ADCP at SOFI from November 2001 to June 2004 are used in order to try to estimate how often the Rhone dilution zone spreads as far east as the SOFI site. The current data is analysed using polar coordinates, with the angle (given in degrees) rotating clockwise and north corresponding to $0^{\circ}$. These currents show that, in average, eastward currents with angle between $45^{\circ}$ and $135^{\circ}$ occur about $20 \%$ of the time from 10 to $140 \mathrm{~m}$ deep (Fig. 8). No real seasonal trends can be isolated. Nonetheless, inertial oscillations are frequent in the zone due to rapid 

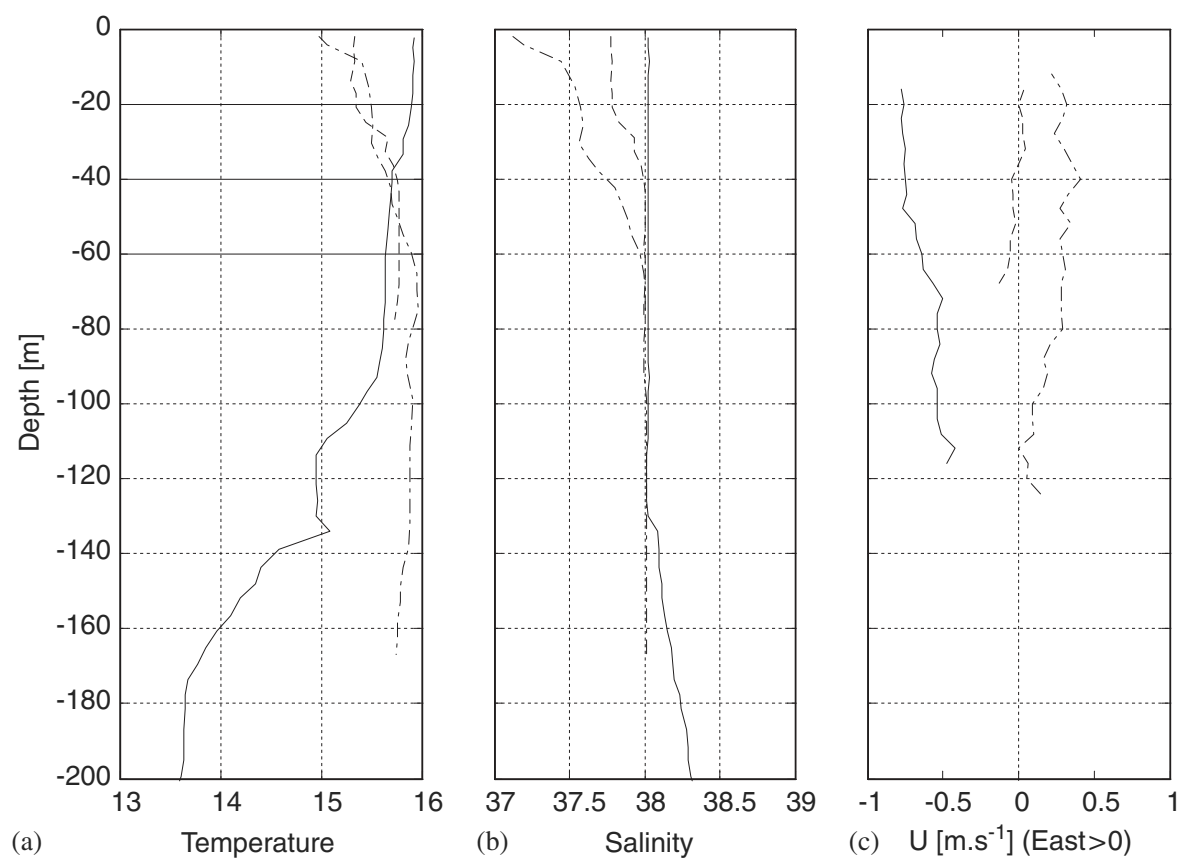

Fig. 6. Vertical profiles on December 10 of: (a) temperature $\left({ }^{\circ} \mathrm{C}\right)$, (b) salinity and (c) west-east current component $\left(U\right.$ in $\left.\mathrm{m} \mathrm{s}^{-1}\right)$ at 3 stations along the $5.13^{\circ} \mathrm{E}$ transect: Station 1 (dashed line), Station 2 (dash-dotted line) and Station 3 (solid line).
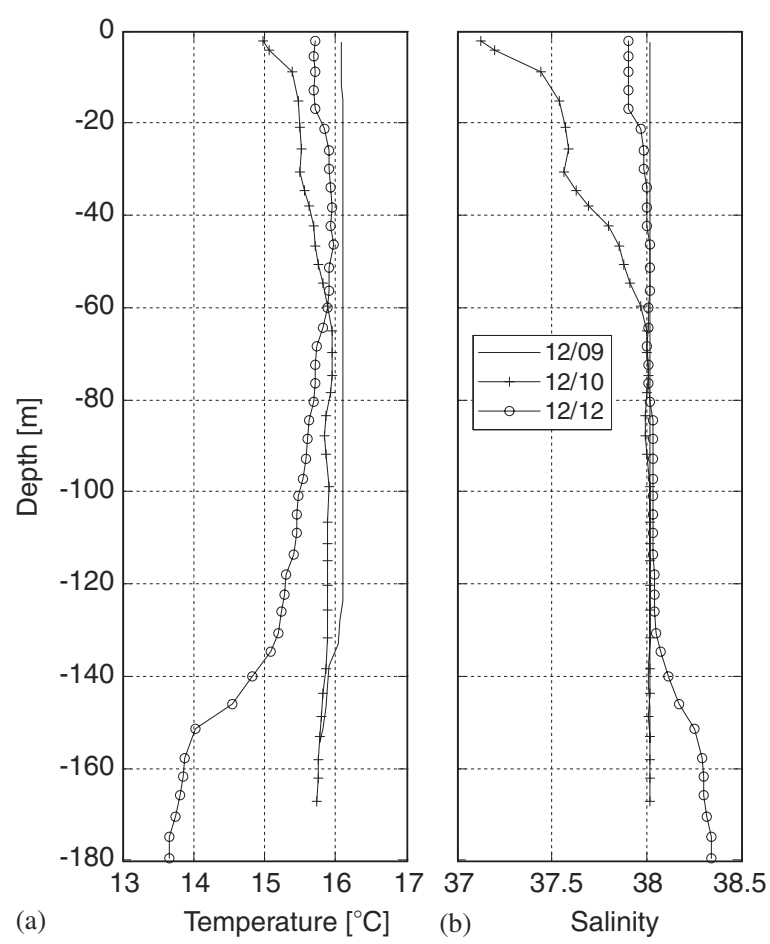

Fig. 7. Vertical profiles at SOFI site of (a) temperature $\left({ }^{\circ} \mathrm{C}\right)$ and (b) salinity. and strong wind variations. In the absence of a barotropic current, these inertial oscillations can generate, among other, temporary eastward currents. In order to subtract any potential influence from inertial oscillations or other high frequency motions, the same analysis was realised on lowpassed filtered currents (with a cut-off period of $20 \mathrm{~h}$ ). The result was close: eastward filtered currents occur about $18 \%$ of the time. It is a rough estimation of the percentage of time the Rhone River could reach the SOFI site. Buoyant waters from the Rhone River need between 16 and $52 \mathrm{~h}$ to reach the SOFI site, for a distance varying from $23.5 \mathrm{~km}$ (distance between the Rhone river mouth and the SOFI site at the latitude of the SOFI site) to $37 \mathrm{~km}$ (distance between the Rhone river mouth and the SOFI site), and for currents' speeds from 20 to $40 \mathrm{~cm} \mathrm{~s}^{-1}$. To guarantee the advection of Rhone River waters to the SOFI site, eastward filtered currents lasting more than 16 and $52 \mathrm{~h}$ are considered. They occur, respectively, about $8.4 \%$ and $3.9 \%$ of the time. Hence diluted waters from the Rhone are estimated to reach the SOFI site between $3.9 \%$ and $8.4 \%$ of the time. The studied event is a relatively rare event. 

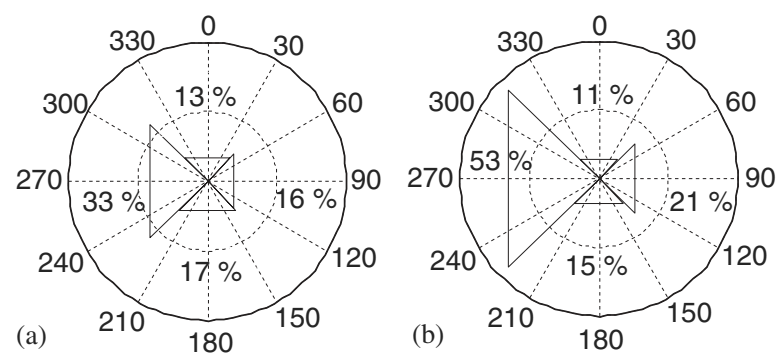

Fig. 8. Rose representation of the horizontal currents measured at SOFI during one year (from June 11, 2003 to June 8, 2004) at (a) $20 \mathrm{~m}$, (b) $120 \mathrm{~m}$. Angles are separated in four classes: $45-135^{\circ}$, $135-225^{\circ}, 225-315^{\circ}$ and $315-45^{\circ}$. Note that the sum of the four percentages is not equal to $100 \%$ at $20 \mathrm{~m}$ depth, due to a certain number of measurements discarded during the ADCP data treatment.

\section{Discussion}

\subsection{Similar behaviour of river plumes}

In the northern hemisphere, other cases of river plumes flowing in the direction opposite to the Coriolis direction have already been studied. For instance, the Mississippi River generally flows westward. But, after the major flood in 1993, while most of the river plume bended to the west, part of it flowed eastward (Walker et al., 1994). According to the authors, the eastward flow was externally forced by abnormal west winds and by a northward intrusion of the Loop Current.

The Changjiang (Yangtze) river, with the third largest discharge in the world, presents seasonally a similar bimodal plume structure consisting of a southward coastal jet and a northeastward spread (Lie et al., 2003). The authors refer to the McCreary et al. (1997), according to which the northward current may be associated with two processes: geostrophic adjustment and Kelvin-wave propagation. The geostrophic adjustment generates a southward flow of salty and fresher water along the plume front that depletes the upstream region from salty waters. Hence, the fresher-water plume must advance northward to replace this loss. The Kelvin wave that propagates downstream from the plume's nose, thins the thickness of the plume layer near the coast. This generates a northward geostrophic coastal current necessary to advect the plume northward. As far as the eastward component of the northeastward spread, Lie et al. (2003) believe that it is due to an offshore current generated by upwelling favourable winds (south winds).
In parallel with the two previous examples and with the coastline orientation of our study, a west wind would have been expected to generate the eastward extent of the Rhone river plume. But, during the present cruise, the wind conditions cannot explain directly the eastward orientation taken by a part of the Rhone river dilution zone.

In the following section, we thus attempt to examine possible mechanisms for the eastward current responsible for this eastern extent.

\subsection{Assumptions on the generating process of the eastern extent of the dilution zone}

The first hypothesis for a generating process is the combination of a storm with east winds and high Rhone river discharges. A portion of the wide (due to the previous high river discharges) Rhone river dilution zone is entrained in the northeastern region of the GoL by a barotropic eastward current. This current appeared on December 9, just after the end of an east wind event. The east wind that blew on December 7 piled water on the western side of the GoL and induced a raise of the sea surface elevation ( $10 \mathrm{~cm}$ observed at Sète tide jauge). An equilibrium state between the pressure gradient (due to the free surface slope) and the wind pressure could then have been reached. But, when the wind stopped on December 8 , the equilibrium broke and the pressure gradient may have created, by relaxation, this eastward current. Nevertheless, this assumption would probably induce a barotropic eastward current along the entire $5.13^{\circ} \mathrm{N}$ transect. While, in the data, the eastward current is barotropic but only localised in the vicinity of the SOFI site (north and south of it, the current is westward). Hence modelling was used to check whether this situation could be reproduced. Very realistic simulations of the Rhone plume and of its dilution zone (Estournel et al., 2001; Reffray et al., 2004) have already been obtained under various meteorological conditions, using the 3D hydrodynamic Symphonie model (Estournel et al., 2003). Thereby, a realistic simulation with this Symphonie model, focused on the December 2003 period and including the whole GoL (Ulses, 2005), was used. This simulation reproduces well the southeast extension of the Rhone river dilution zone after the east wind event on December 8. Indeed, the simulated dilution zone (corresponding to the 37.8 isohaline) extends to the SOFI site and even further east as far as $5.46^{\circ} \mathrm{E}$ on December 11 (Fig. 9). This extension is associated to 
an eastward current in front of the Camargue coast, that turns to the southeast east of the Gulf of Fos (Fig. 9). This eastward current is located slightly further northeast than in the observations. But, as in the data, it does not cover the entire $5.13^{\circ} \mathrm{N}$ transect as it was thought it could. Actually, the circulation features developing on the rest of the continental shelf are highly complex and variable and hence, occurring simultaneously, can prevent a process from being observed entirely. At the grid point corresponding to the SOFI mooring, the dilution zone reaches $50 \mathrm{~m}$ depth (not shown), which is consistent with the observations. As the simulation reproduces the vertical and horizontal extensions of the Rhone plume evidenced by the observations, this model can be used to make some sensitivity tests. These sensitivity tests reveal that the eastward current disappears when a null wind speed is imposed during the east wind event, or is significantly reduced when the freshwater discharge is omitted. So, in the specific case studied here, the eastern extent of the dilution zone is due to the combined effects of east winds and the presence of freshwater along the coast. On December 4, 2003, a storm with east winds simultaneous to the intense flood already mentioned also occurred. An eastward current is numerically (data not shown) observed east of the Rhone river mouth until the December 7 when the second east wind stopped it. This current is less intense and more coastal than the one described in this paper (which occurred 4 days after) and hence did not bring Rhone river diluted waters to the SOFI site. The succession of two east wind events and the consequent presence of freshwater along the coast could explain the difference between these two eastward currents.

On June 17-19, 1998, a barotropic eastward current (Petrenko, 2003) and diluted CW $(S<37.7$ on $20 \mathrm{~m}$ deep; Diaz, 2000) have been detected at the SOFI site at the end of an 8-day Mistral event. Also, as mentioned in the introduction (Section 1), another case of barotropic eastward current associated with diluted $\mathrm{CW}$ ( $S<37.8$ on $50 \mathrm{~m}$ deep) has been observed during the GOLTS cruise, on December 1-2, 2002. It was north of the SOFI site (at $43.25^{\circ} \mathrm{N}$ ) and occurred after a quick succession of wind conditions (southeast, rest and strong Mistral). This shows that winds other than east wind (as in our first hypothesis) can generate such eastward currents. Hence, for other events than the December 2003 one, other hypotheses of generating process are proposed.

Our second hypothesis about the origin of this eastward current is based on the NC mesoscale activity (particularly strong in the winter, Albérola et al., 1995; Sammari et al., 1995). The NC

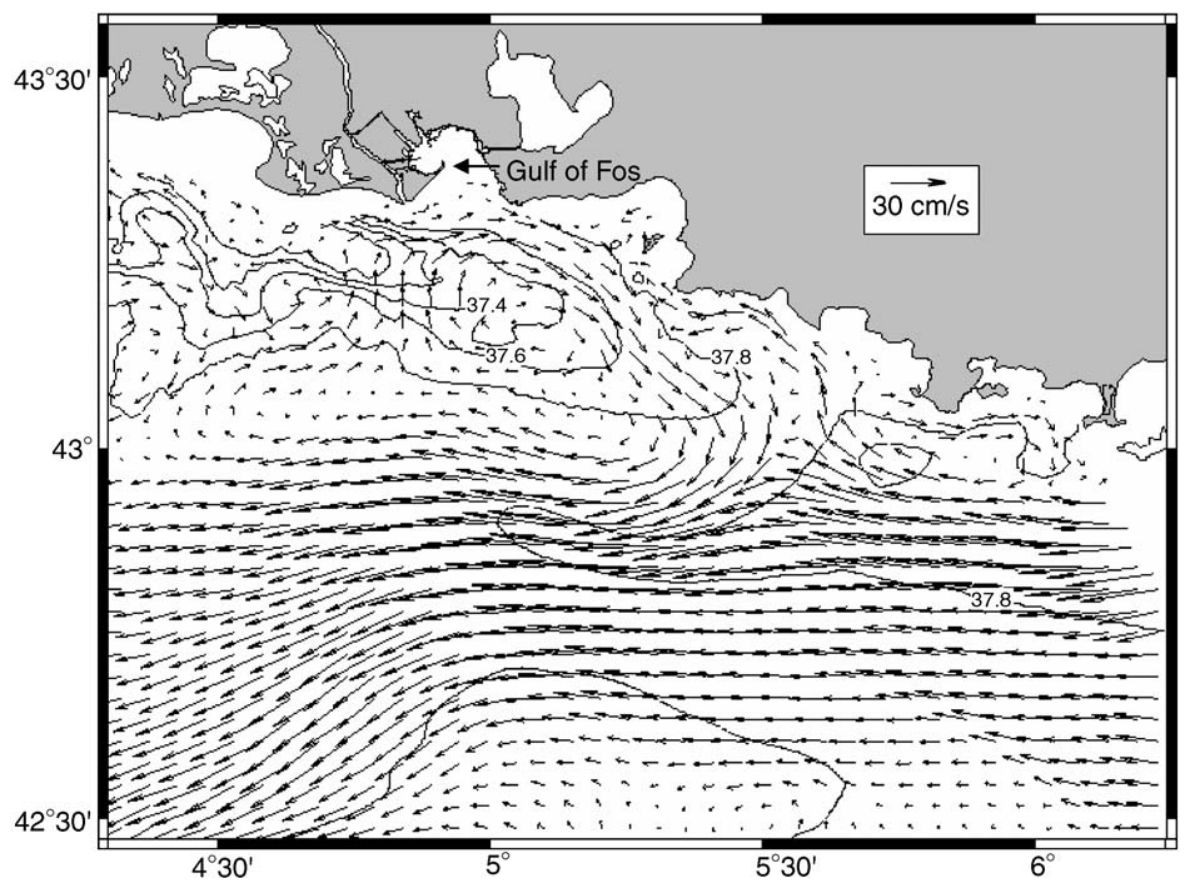

Fig. 9. Computed salinity (contours every 0.2 ) and current (arrows; $\mathrm{cm} \mathrm{s}^{-1}$ ) at $24 \mathrm{~m}$ depth on December 11 at $00 \mathrm{~h}$. 
meanders along the GoL's shelf break (Flexas et al., 2002, Petrenko, 2003). An anticyclonic eddy could have detached from a NC's meander in the region of the SOFI site. The eastward current, detected at SOFI, could be the northern part of this eddy, carrying Rhone river waters eastward. The offshore transport of buoyant water by eddies and meanders at the shelf break have already been observed in other regions of the world ocean. Along the northwestern coast of the Black Sea, during the 1993 summer, the Danube river, instead of flowing southward as usual, was entrained eastward by mesoscale eddies present at the shelf break (Ginzburg et al., 2002; Yankovsky et al., 2004). However, such eddies and meandering motions are commonly attributed to baroclinic instability (Flexas et al., 2002) while the observed eastward current is barotropic. Moreover, there is no eddy clearly visible near the SOFI site, neither on the December 2002 and 2003 AVHRR images, nor on the June 1998 SeaWiFs images.

Hence, we suggest a third hypothesis that takes into account more complex generating processes that includes the effects, not only of the wind, but also of the local circulation and bathymetry. Indeed, the eastward current could be one of the GoL's circulation features developing on the continental shelf, such as anticyclonic eddies (linked to the wind curl) developing on the western side of the GoL (Estournel et al., 2003; Petrenko, 2003) or anticyclonic eddies trapped at topographic irregularities due to the interaction between barotropic shelf wave and the NC flowing along the shelf break (Yankovsky and Chapman, 1997). Due to the shapes of the coastline and of the continental slope, these anticyclonic eddies could induce eastward shelf currents towards the SOFI site. The data available with the hull-mounted ADCP do not cover the entire eastern GoL and hence make it difficult to check this last hypothesis.

\section{Conclusions and perspectives}

The analysis of in situ measurements and satellite images during the December 2003 GOLTS cruise reveals an unusual orientation of part of the Rhone river dilution zone towards the east. Scientists have rarely noticed this event during the previous decades, in contrary to the Changjiang extent, which is a seasonal event. Besides, it is the first time that the dilution influence has been observed down to $40 \mathrm{~m}$ at the SOFI site, whereas this site is far $(37 \mathrm{~km})$ from the Rhone river mouth. This eastern extent is due to the presence of a barotropic eastward current, clearly detected by the ADCP measurements. Results from studies on similar behaviour of river plumes do not clarify the origin of this eastward current. But modelling work allows to confirm our first hypothesis: the eastern extension of the plume, observed in December 2003, is due to the combination of a storm with east winds and the presence of Rhone freshwater along the coast.

However, other similar events, noticed during previous cruises in the GoL, do not occur after east winds. This leads us to make two other hypotheses about the generating processes of such eastern extensions. Satellite data contradict the second hypothesis so only the third one, concerning a combined effect of the local shelf's circulation, the $\mathrm{NC}$ and the bathymetry, remains possible. But current and hydrology data on the entire GoL would be necessary to check this hypothesis.

So, the present study suggests that setting a mooring network (with ADCP, temperature and salinity sensors) in this area would be extremely useful. Indeed, if such data were collected, they would show which percentage of time the Rhone river diluted waters are associated with eastward currents and reach the SOFI site. This would also allow us to check our rough estimation (3.9-8.4\%) of the occurrence of such event. Unfortunately, strong fishing activity tends to threaten moorings in the area and may be a problem if an extended array of moorings was to be deployed.

Besides, more numerical modelling work would be useful to further explore the complex behaviour of the plume when an eastern extent of the Rhone river dilution zone is observed and test each specific wind and discharge conditions encountered. It would also allow us to test our third hypothesis and gain understanding on the various forcing terms responsible for this unusual feature. Moreover, coupled to a biogeochemical model, one could also test what impact the eastern extent of the Rhone dilution zone has on the eastern GoL's ecosystem.

\section{Acknowledgements}

The GOLTS cruises and study were supported by the PATOM program (Programme Atmosphère et Océan à Multi-échelles). We are grateful to the crews of the R/V Tethys II, Gilles Rougier and Jean-Luc Fuda for their help. We also thank 
Pierre-Michel Theveny (from DT/INSU) for the ADCP data analysis.

\section{References}

Albérola, C., Millot, C., Font, J., 1995. On the seasonal and mesoscale variabilities of the Northern Current during the PRIMO-0 experiment in the western Mediterranean Sea. Oceanologica Acta 18 (2), 163-192.

Albérola, C., Millot, C., 2003. Circulation in the French mediterranean coastal zone near Marseilles: the influence of wind and the Northern Current. Continental Shelf Research 23, 587-610.

Arnoux-Chiavassa, S., 1998. Modélisation d'écoulements côtiers stratifiés présentant des fronts: application au panache du Rhône. Ph.D. Thesis, Université de Toulon et du Var, France, $250 \mathrm{p}$.

Arnoux-Chiavassa, S., Rey, V., Fraunié, P., 2003. Modeling 3D Rhone river plume using a higher order advection scheme. Oceanologica Acta 26, 299-309.

Broche, P., Devenon, J.L., Forget, P., De Maistre, J.C., Naudin, J.J., Cauwet, G., 1998. Experimental study of the Rhone plume. Part I: physics and dynamics. Oceanologica Acta 21, 725-738.

Chao, S.-Y., 1988. Wind driven motion of estuarine plumes. Journal of Physical Oceanography 18, 1144-1166.

Conan, P., 1996. Variabilité et bilan de la production primaire en zone côtière (Méditerranée Nord occidentale; entrée du golfe du lion) en relation avec les systèmes biologique, chimique et hydrodynamique (Courant Nord Méditerranéen) (tome I) Ph.D. Thesis, Université Aix Marseille 2, France, 200pp.

Coste, B., 1974. Rôle des apports nutritifs minéraux rhodaniens sur la production organique des eaux du Golfe du Lion. Téthys 6, 727-740.

Coste, B., Raimbault, P., 1993. Recent data on the nutrient input into the Mediterranean Sea by the Rhone river. In: Martin, J.M., Bdarth, B. (Eds.), EROS-2000, Nerc, Plymouth, UK, Water Pollution Research Reports 30, 47-50.

Demarcq, H., 1985. Applications de la télédétection infrarouge et visible en océanographie. Ph.D. Thesis, Université AixMarseille 2, France, 237pp.

Diaz, F., 2000. Evolution saisonnière de la production primaire et des processus d'assimilation-régénération de l'azote dans le Golfe du Lion. Estimation d'un bilan de carbone. Approches in situ et modélisation (tome I). Ph.D. Thesis, Université AixMarseille 2, France, 270pp.

Devenon, J.L., Broche, P., De Maistre, J.C., Forget, P., Gagelli, J., Rougier, G., 1992. VHF radar measurements in the Rhone river plume. Water Pollution Research Reports 28, 75-87.

Durand, N., Fiandrino, A., Fraunié, P., Ouillon, S., Forget, P., Naudin, J.J., 2002. Suspended matter dispersion in the Ebro ROFI: an integrated approach. Continental Shelf Research 22, 267-284.

Durrieu de Madron, X., Denis, L., Diaz, F., Garcia, N., Guieu, C., Grenz, C., Loÿe-Pilot, M.-D., Ludwig, W., Moutin, T., Raimbault, P., Ridame, C., 2003. Nutrients and carbon budgets for the Gulf of Lion during the Moogli cruises. Oceanologica Acta 26, 421-433.
Estournel, C., Kondrachoff, V., Marsaleix, P., Vehil, R., 1997. The plume of the Rhone: numerical simulation and remote sensing. Continental Shelf Research 17, 899-924.

Estournel, C., Broche, P., Marsaleix, P., Devenon, J.L., Auclair, F., Vehil, R., 2001. The Rhone River plume in unsteady conditions: numerical and experimental results. Estuarine Coastal and Shelf Science 53, 25-38.

Estournel, C., Durrieu de Madron, X., Marsaleix, P., Auclair, F., Julliand, C., Vehil, R., 2003. Observation and modeling of the winter coastal oceanic circulation in the Gulf of Lion under wind conditions influenced by the continental orography (FETCH experiment). Journal of Geophysical Research 108 (C3), 8059.

Fieux, M., 1974. Formation d'eau dense sur le plateau continental du Golfe du Lion. Colloques Internationaux du CNRS, La formation des Eaux Océaniques Profondes, CNRS, Paris.

Flexas, M.M., Durrieu de Madron, X., Garcia, M.A., Canals, M., Arnau, P., 2002. Flow variability in the Gulf of Lions during the MATER HFF experiment (March-May 1997). Journal of Marine Systems 33-34, 197-214.

Forget, P., Devenon, J.L., De Maistre, J.C., Broche, P., Leveau, M., 1990. VHF remote sensing for mapping river plume circulation. Geophysical Research Letters 17, 1097-1100.

Garvine, R.W., 1995. A dynamical system for classifying buoyant coastal discharges. Continental Shelf Research 15 (13), 1585-1596.

Ginzburg, A.I., Kostianoy, A.G., Nezlin, N.P., Soloviev, D.M., Stanichny, S.V., 2002. Anticyclonic eddies in the Northwestern Black Sea. Journal of Marine Systems 32, 19797-19807.

Leblanc, K., Queguiner, B., Garcia, N., Rimmelin, P., Raimbault, P., 2003. Silicon cycle in the NW Mediterranean Sea: seasonal study of a coastal oligotrophic site. Oceanologica Acta 26, 339-355.

Lie, H.-J., Cho, C.-H., Lee, J.-H., Lee, S., 2003. Structure and eastward extension of the Changjiang River plume in the East China Sea. Journal of Geophysical Research 108 (C3), 3077.

Marsaleix, P., Estournel, C., Kondrachoff, V., Vehil, R., 1998. A numerical study of the formation of the Rhone River plume. Journal of Marine Systems 14, 99-115.

McCreary Jr., J.P., Zhang, S., Shetye, S.R., 1997. Coastal circulation driven by river outflow in a variable-density 11 / 2-layer model. Journal of Geophysical Research 102 (C7), 15535-15554.

Millot, C., Wald, L., 1980. The effect of Mistral wind on the Ligurian current near Provence. Oceanologica Acta 3, 399-402.

Millot, C., 1990. The Gulf of Lion's hydrodynamics. Continental Shelf Research 10, 885-894.

Minas, M., Minas, H.J., 1989. Primary production in the Gulf of Lions with considerations to the Rhone river input. Water Pollution Research Reports 13, 112-125.

Morel, A., Bricaud, A., André, J. M., Pelaez-Hudlet, J., 1990. Spatial-temporal evolution of the Rhône River plume as seen by CZCS imagery: consequences upon primary productions in the Gulf of Lions. In: Martin, J.-M., Barth, H. (Eds.), EROS2000, Nerc, Plymouth, UK, Water Pollution Research Reports 20, 45-62.

Petrenko, A., 2003. Variability of circulation features in the Gulf of Lion NW Mediterranean Sea. Importance of inertial currents. Oceanologica Acta 26, 323-338. 
Reffray, G., Fraunié, P., Marsaleix, P., 2004. Secondary flows induced by wind forcing in the Rhône region of freshwater influence. Ocean Dynamics 54, 179-196.

Sammari, S., Millot, C., Prieur, L., 1995. Aspects of the seasonal and mesoscale variabilities of the Northern Current in the western Mediterranean Sea inferred from PROLOG-2 and PROS-6 experiments. Deep-Sea Research I 42 (6), 893-917.

Ulses, C., 2005. Dynamique océanique et transport de la matière particulaire dans le Golfe du Lion: crue, tempête, période hivernale. Ph.D. Thesis, Universite Paul Sabatier, France, $247 \mathrm{pp}$.

UNEP/ECE/UNIDO/FAO/UNESCO/WHO/IAEA, 1984. Pollutants from land based sources in the Mediterranean. Regional Seas reports and Studies, 32.
Walker, N.D., Fargion, G.S., Rouse, L.J., Biggs, D.C., 1994. The great flood of summer 1993: Mississippi River discharge studied. Eos Transactions of AGU 75 (36), 409.

Xing, J., Davies, A.M., 1999. The effect of wind direction and mixing upon the spreading of a buoyant plume in a non-tidal regime. Continental Shelf Research 19, 1437-1483.

Yankovsky, A.E., Chapman, D.C., 1997. Anticyclonic eddies trapped on the continental shelf by topographic irregularities. Journal of Geophysical Research 102 (C3), 5625-5639.

Yankovsky, A.E., Lemeshko, E.M., Ilyin, Y.P., 2004. The influence of shelfbreak forcing on the alongshelf penetration of the Danube buoyant water, Black sea. Continental Shelf Research 24, 1083-1098. 